\title{
Ecological Health Assessment of Renuka Lake, Himachal Pradesh, India
}

\author{
Yeshi Choden*†, M. P. Sharma**, Gaurav Pandey**, S. K. Gupta** and K. D. Dema*** \\ *Department of Civil Engineering, College of Science and Technology, Royal University of Bhutan, 21101, Bhutan \\ **Department of Hydro and Renewable Energy, Indian Institute of Technology, Roorkee-247667, Uttarakhand, India \\ ***Department of Information and Technology, College of Science and Technology, Royal University of Bhutan, \\ 21101, Bhutan \\ $†$ Corresponding author: Yeshi Choden; yeshichoden.cst@ rub.edu.bt
}

Nat. Env. \& Poll. Tech.

Website: www.neptjournal.com

Received: 02-06-2021

Revised: 23-06-2021

Accepted: 13-07-2021

Key Words:

NFSWQI

Water quality index (WQI)

Ecological health index

Diversity index

\section{ABSTRACT}

Researchers, policymakers, and governments are increasingly interested in assessing the ecological health $(\mathrm{EH})$ of lakes and streams. The $\mathrm{EH}$ of a lake can be expressed in terms of water quality, trophic state and biodiversity of riparian vegetation, macroinvertebrates and fishes. The ecological health index (EHI) of Renuka lake, Himachal Pradesh of India, was analyzed based on National Sanitation Foundation Water Quality Index (NSFWQI), Carlson's Trophic State Index (TSI), Simpson Diversity Index (SDI), and Shannon-Weiner index (SWI). The results of NSFWQI and CTSI are found in the range of 40-59 and 49.9-58.9 respectively indicating that the water quality was poor to medium and not suitable for drinking purposes but can be used for secondary purposes such as agriculture, industry, and recreation etc. The trophic state of the lake is similarly in the eutrophic range, with an overall EHI of 1.81-2.47, indicating poor to medium trophic status. Apart from analyzed results, the $\mathrm{EH}$ category from mesotrophic to a eutrophic state of the lake is caused due to the cultural siltation/nutrient loading, religious practices, land tenurial issues, and uncontrolled tourist pressure followed by recreational activities on water bodies and lake vicinity. Accordingly, suitable restoration methods such as source control, desilting/dredging, and lake aquatic plantation are suggested to recover the ecological health of the lake back to a mesotrophic or oligotrophic state.

\section{INTRODUCTION}

The water resources, mainly, rivers, lakes, glaciers, rainwater, groundwater, etc., meet the need for water for drinking, agriculture, livestock production, forestry, industrial activities, hydropower generation, fisheries, and other creative activities. The quality of both surface and groundwater is deteriorating rapidly due to the increasing population, industrialization, urbanization, etc (Tyagi et al. 2020). These sectors directly dispose huge quantities of untreated urban and industrial effluents to nearby drains/water bodies, thus building up high concentrations of toxic pollutants and contaminating the resources (Choden et al. 2020). Out of various water bodies, lakes, a large area of variable sizes filled with water and surrounded by land, constitute an important part of the landscape, having no direct exchange of water with the ocean but provide extremely valuable ecosystems and goods and services to humankind (Cantonati et al. 2020). The EH assessment of such water bodies is based on their ecosystem health, which encompasses not only the water quality but also the diversity of plants and organisms that populate there. A lake or any water body has both, natural and social attributes each contributing to its overall health. Ecosystem or Ecological Health (EH) is defined by the interaction between lake biota and their hydrodynamical and geochemical environment. Therefore, it depends on the diversity of habitats of plants and animal species and also on the effectiveness of the linkages and maintenance of ecological processes including its water quality. In recent years, there has been a lot of research on this topic. For example, (Kumar et al. 2015) analyzed the EH of Baiyangdian lake in China using the ecological health index and classified the EH as a medium: 40-60. (Yadav et al. 2015) determined the EH of the Chambal River using EQI and RPI methods based on WQ parameters and found that water parameters are the most important tool for assessing overall river health, and the $\mathrm{EH}$ of the river was found satisfactory in the range of 1-2, indicating that the water is not suitable for drinking but is suitable for irrigation, bathing, and aquaculture. (Sharma et al. 2010) used WQ and the Trophic State Index (TSI) to assess the EH of Mansi Ganga Lake in Vrindavan, Uttar Pradesh, India. They found that the lake was oligotrophic in 2006 but became mesotrophic later and that in 2008, there was a significant increase in pollution due to massive algae growth. The treatment of algae with copper sulphate was proposed and used, followed by the draining of all toxic water and the refilling of the lake with canal water. This had made a huge 
difference in the lake's health. Further, the water quality assessment of Nanital lake of Uttrakhand, India was carried out by (Sharma 2014) using physio-chemical parameters and found the lake was highly polluted due to receiving illegal disposal of construction wastes and discharge of domestic and industrial wastewater including agriculture runoffs from the catchment. The lake restoration was carried out by using 35 discs embedded at the lake bottom for the purpose of oxygenation of the lake, stratification breakage, and catchment area remediation. This has restored the lake to an oligotrophic state, making it a role model for lake management. It has also reclaimed its natural beauty, as seen by the influx of large numbers of tourists desiring navigation and natural beauty. The Surha Lake, located in district Ballia of Uttar Pradesh, India, is the main source of livelihood for the local population which has been badly affected by a huge growth of algae due to receiving huge agricultural runoffs and wastewater from the surrounding population. The EH of this lake was conducted during the wet and dry season from 2014 to 2015 using EHI based on NSFWQI, CTSI, and SDI. The results indicated that the lake was in a eutrophic state both during the wet and dry seasons with an average CTSI of 76.30 and 79.49 respectively, thereby, indicating the poor quality of water as unsuitable for human use. The SDI was found as 0.67 and 0.65 in wet and dry seasons i.e., poor diversity (Mishra et al. 2016). (Sunil et al. 2016) studied the structure and diversity of riparian forests across forest and agro-ecosystem landscapes along the river Cauvery of southern India using the Shannon-Wiener Index (SWI) method. The results showed that the expansion of agricultural activities and other biotic pressures might have led to the variation in species composition between the forest and agro-ecosystem, declining some evergreen species, subsequently affecting the connected biodiversity of the river in the agro-ecosystem.

According to the above literature, EH assessments of various Himalayan and mountain lakes are lacking and no work on Renuka Lake, a Ramsar site, in terms of ecological and biodiversity health is available. Renuka Lake is a sacred lake in Himachal Pradesh, India, that has been designated as a Ramsar site. Because of the importance of Renuka Lake and the benefits it provides to the local community, the current study was done to assess the lake's ecological health. The findings are likely to be valuable to policymakers and stakeholders in the future to restore it.

\section{MATERIALS AND METHODS}

\section{About the Study Area}

A religious Renuka lake lies in the Sirmaur district of Hi- machal Pradesh and its location map and lake catchment are shown in Fig. 1. This natural Ramsar lake has a wildlife sanctuary covering one-third of its circumference in its catchment making it a center of attraction. Renuka Lake has a small outlet that drains its water to Parshhuram Tal, a manmade pool, and then to River Giri, a tributary of the Yamuna River. Its maximum depth is approximately $13 \mathrm{~m}$ and minimum about $0.5 \mathrm{~m}$. Its maximum length is $1706.7 \mathrm{~m}$ and its width is in the range of $132.5-246.8 \mathrm{~m}$. Its shoreline length is $3214 \mathrm{~m}$, surface area and catchment areas are 0.18 $\mathrm{km}^{2}$ and $2.5 \mathrm{~km}^{2}$ respectively (Singh 2012) and (Diwate et al. 2020).

Renuka lake is a perennial water body fed by 21 seasonal streams which remain vigorously full of water, particularly, during the monsoon season. The internal springs of the lake are the perennial source of water. The underground network of channels in the Limestone and Dolomite formations of the area are possible conduits to get the groundwater to the lake. Given its rich biodiversity and uniqueness of the area, the Renuka lake was declared as a Ramsar site in the year 2005. The climate of the area is of sub-tropical monsoonal type. Renuka Lake receives $150-199.9 \mathrm{~cm}$ of precipitation each year, with an average maximum temperature of $32^{\circ} \mathrm{C}$. Low-lying locations experience warm winters, whereas high mountain ranges experience snowfall. Springtime is warm and sunny. The rainy seasons are the wettest parts of the year, with high levels of humidity. During the monsoon season,

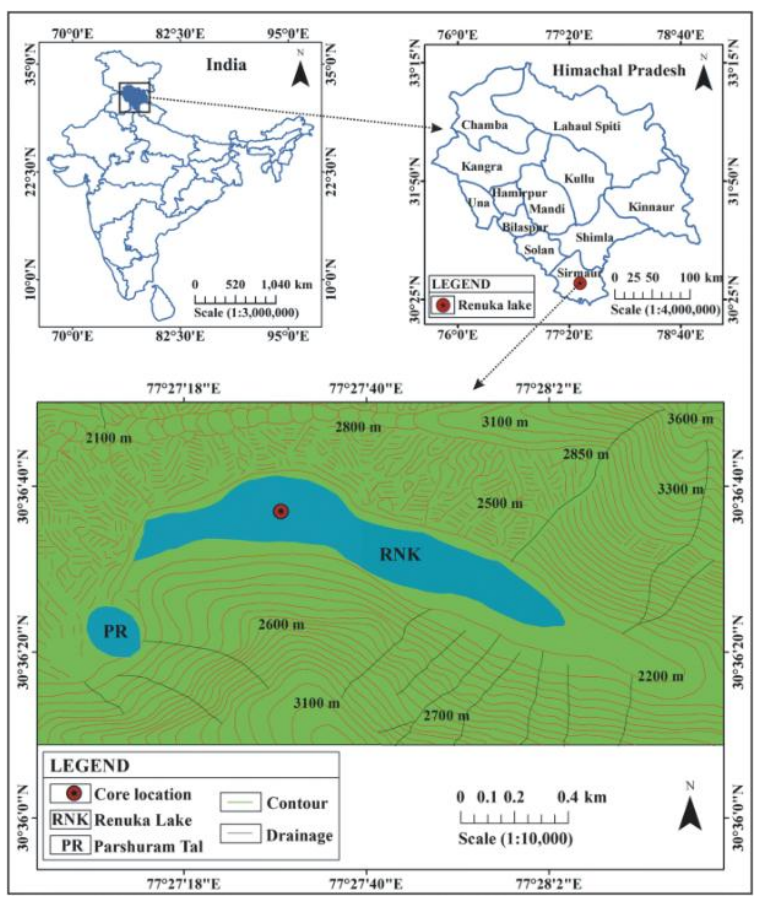

Fig. 1: Renuka lake. 
the summers are scorching hot (Himachal Pradesh Council for Science, Technology \& Environment 2017).

\section{Sample Collection for WQI Assessment}

A total of 15 samples were collected from 5 locations during pre and post-moon 2018-2019 as shown in Fig. 2 and data analysis is presented in Table 3 which gives the details of sampling locations. All the WQ parameters are the average values of all the 3 samples from each site. Fig. 3 gives a spatial representation of each water quality parameter. The samples were analyzed for temperature, $\mathrm{pH}$, total solids, total suspended solids, and total dissolved solids, turbidity, transparency, specific conductivity, dissolved oxygen, alkalinity, total hardness, calcium, and magnesium hardness, nitrates, phosphates, sodium, COD, BOD, E. coli, and $\mathrm{pH}$ as per the standard procedures (APHA 2018).

The parameters like temperature, $\mathrm{pH}$, turbidity, fecal coliforms, dissolved oxygen (DO), BOD, total phosphates (TP), COD and total solids (TS) were converted to NFSWQI (Tyagi et al. 2020). The mathematical expression of this index is given by Eq. 1:

$$
\mathrm{WQI}=\sum_{\mathrm{i}=1}^{\mathrm{n}} \mathrm{QiWi}
$$

Where $\mathrm{Q} i=$ sub-index for $\mathrm{i}^{\text {th }}$ water quality parameter; $\mathrm{Wi}=$ weight associated with $\mathrm{i}^{\text {th }}$ water quality parameter; $\mathrm{n}=$ number of water quality parameters.

\section{Arc-GIS Interpolation and Spatial Representation}

To predict water quality status at various locations of the lake, the water quality parameters of 15 samples as reported in Table 3, were interpolated using arc-GIS and spatially represented using inverse distance weighted technique (IDW) (Childs 2004, Ozturk \& Kilic 2016). Fig. 3 gives spatial reference as to how each parameter is concentrated

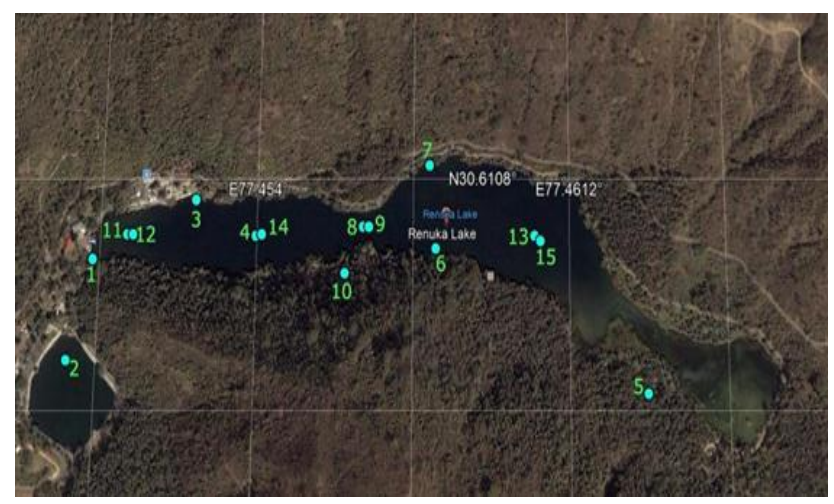

Fig. 2: Sample collection points. throughout the lake and how critical the level of pollution is based on each quality parameter.

\section{Trophic State Index (TSI)}

The trophic status refers to the level of productivity in a lake as measured by Total phosphorous (TP), algal abundance in terms of Chlorophyll (Chlor), and Secchi depth (SD) for the extent of light penetration. TSI rates individual lakes, ponds, and reservoirs based on the amount of biological productivity occurring in the water body. Using TSI, one can get a quick idea about the extent of productivity and hence the health of a lake (Hillsborough 2008). The well-known Carlson TSI can be used to rank lakes based on pollution and biomass productivity both within and between regions. This ranking allows water managers to focus on lakes that may require restoration or conservation efforts in the future. An increase in the trend of TSI over a period of several years may indicate the level of degradation of the health of the lake. The CTSI is briefly discussed below:

Carlson's Trophic Status Index: Carlson (Carlson 1977) developed CTSI in the year 1977 based on WQ parameters like Total P, Chlorophyll, and Secchi depth.

The following equations are used to compute CTSI of a lake:

$$
\begin{aligned}
& \text { TSI }-\mathrm{P}=14.42 * \operatorname{Ln}[\mathrm{TP}]+4.15\left(\text { in ug. } \mathrm{L}^{-1}\right. \text { ) } \\
& \text { TSI }-\mathrm{C}=30.6+9.81 \mathrm{Ln}[\text { Chlor-a }] \text { (in ug. } \mathrm{L}^{-1} \text { ) } \\
& \text { TSI }-\mathrm{S}=60-14.41 * \mathrm{Ln}[\mathrm{SD}](\text { in meters) }
\end{aligned}
$$

Average TSI $=[$ TSI $(\mathrm{P})+$ TSI (Chlor ' $\mathrm{a}$ ') + TSI (SD) $] / 3$

Where TP is total phosphorus, chlor-a is chlorophyll ' $a$ ', SD is the Secchi depth. Table 1 gives the range of index values showing the trophic status of the lake.

\section{Diversity Index (DI) of Riparian Vegetation}

DI depends on the patterns of species distribution and abundance and gives a fair idea about lake health. For Riparian vegetation, the entire length of Renuka Lake was divided into 10 plots (five on each side of the length of the lake), each plot had a dimension of $1 \mathrm{~m} * 1 \mathrm{~m}$. The plant or vegetation species were counted and their abundance ratio was calculated as presented in Table 5, which is further used as a parameter to determine DI. DI is a mathematical tool to express the number of species in a biological community used to understand the community structure. It provides information about community composition and species richness by taking the relative abundances of different species available. The riparian zone consists of stream banks and floodplain vegetation (Mendes et al). The following DIs were calculated based on the ecological indicator handbook (Jorgenus et al. 2016). 


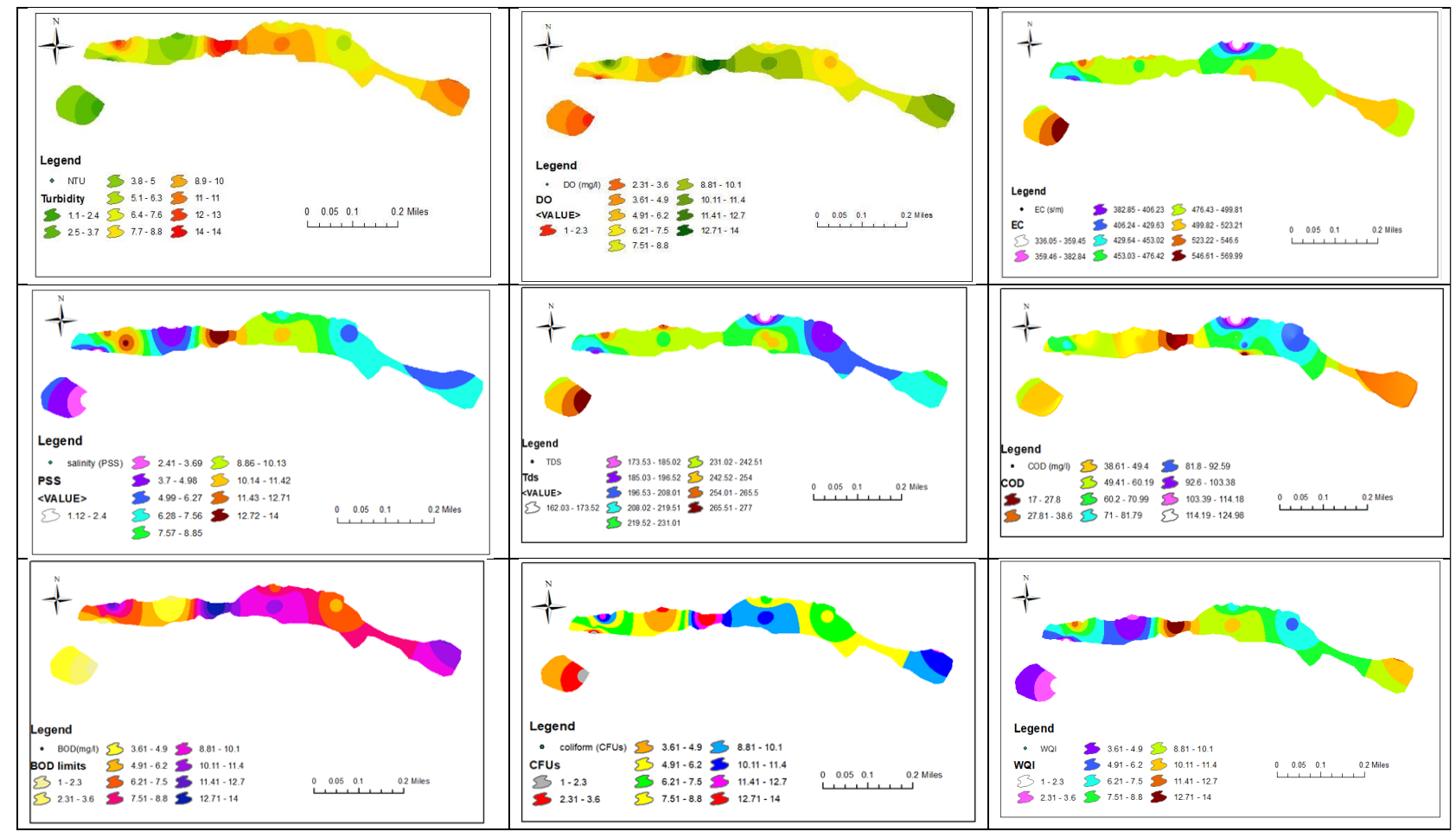

Fig. 3: Interpolated spatial representation of water quality parameters throughout the lake.

Table 1: Range of index values showing the trophic class (Pavluk \& Vaate 2018).

\begin{tabular}{|lllll|}
\hline TSI & Chl. & P & SD & Trophic status \\
\hline$<30-40$ & $0-2.6$ & $0-12$ & $>8-4$ & $\begin{array}{l}\text { Oligotrophic: Clearwater, oxygen throughout the year in } \\
\text { the entire hypolimnion. } \\
\text { Mesotrophic: water moderately clear; increasing proba- } \\
\text { bility of hypolimnetic anoxia during summer }\end{array}$ \\
$50-50$ & $2.6-20$ & $12-24$ & $4-2$ & $\begin{array}{l}\text { Eutrophic: anoxic hypolimnia, macrophyte problem } \\
\text { possible } \\
70-100^{+}\end{array}$ \\
$20-56$ & $24-96$ & $2-0.5$ & $\begin{array}{l}\text { Hypereutrophic: dense algae and macrophytes, algal } \\
\text { blooms possible throughout summer. }\end{array}$ \\
\hline
\end{tabular}

Shannon-Wiener Index: This is based on the information theory and assumes that individuals are sampled at random out of an "indefinitely large" community and that all the species are represented in the sample. The index is represented by Eq. 2:

$$
\mathrm{H}^{\prime}=-\Sigma \mathrm{p}_{\mathrm{i}} \log \mathrm{p}_{\mathrm{i}}
$$

Where $p_{i}$ is the proportion of individuals found in the species i.

The index ranges between 0 and 5 . Higher value implies higher diversity
Simpson Index: It is based on the probability that two individuals randomly extracted from an infinitely large community belong to the same species: It is expressed by Eq. 3 as:

$$
\mathrm{D}=\sum\left[\frac{\mathrm{ni}(\mathrm{ni}-1)}{\mathrm{N}(\mathrm{N}-1)}\right]
$$

Where ni is the number of individuals in the species $\mathrm{i}$ and $\mathrm{N}$ is the total number of individuals.

It ranges from 0 to 1 where a higher value implies a low diversity and vice-versa. 


\section{Ecological Health Index (EHI)}

EHI was proposed by Joshi (2013) to assess the EH of a water body based on NSFWQI and CTSI. Further, the EHI equation was modified by adding SDI to WQI and CTSI as reported by (Yadav et al. 2015). The final equation to calculate the overall EHI of the lake is represented by Eq. 4. Table 2 reports the results of WQI, CTSI and DI converted into EHI scores.

The resulting scores (EHI of NSFWQI and CTSI) and SDI were used to evaluate EHI mathematically as shown by Eq. 4:

$$
\mathrm{EHI}=\frac{\left[\mathrm{EHI}(\mathrm{CTSI})+\mathrm{EHI}(\mathrm{WQI})+\left(\frac{1}{\mathrm{SDI}}\right)\right]}{3}
$$

Where EHI (CTSI) is the score for CTSI; EHI (WQI) is the score for WQI. The EHI range from 0-5 and classifies the ecological health of a water body as: excellent (0-1); good (1-2); average (2-3); poor (3-4); and very poor (4-5).

\section{RESULTS AND DISCUSSION}

All the WQ parameters of 15 samples (3 samples at each site) were interpolated using arc-GIS to predict the concentration level of each parameter throughout the lake indicating the pollution level. Locations 2 and 3 (bathing and recreational area) had higher TDS, Turbidity, COD, BOD, Salinity, and total Coliform limits, as shown in the color-coded legend in Fig. 3, indicating water pollution. Similarly, the NSFWQI data in Table 3 shows that overall lake water quality ranged from poor to medium, with locations 2 and 3 being the most polluted, with NSFWQI values in the 40-45 range.

Furthermore, the CTSI indicates that the lake is eutrophic both before and after the monsoon. The bathing ghat and recreational area at locations $2 \& 3$ had a higher level of eutrophication (Table 4), which could be owing to the nearby location having the popular Himachal Pradesh temple, Renukaji temple, which is situated on the lake's bank and attracts a large number of pilgrims/tourists (Pillai 2003). Weathering rocks/catchment, which regulates the principal

Table 2: EHI based on WQI \& CTSI (Joshi 2013).

\begin{tabular}{|lllll|}
\hline NSFWQI & Carlson's TSI & EHI & EHI Range & Status \\
\hline $90-100$ & $10-30$ & 1 & $0-1$ & Excellent \\
$70-90$ & $30-50$ & 2 & $1-2$ & Good \\
$50-70$ & $50-70$ & 3 & $2-3$ & Medium \\
$25-50$ & $70-90$ & 4 & $3-4$ & Poor \\
$0-25$ & $90-100$ & 5 & $4-5$ & Very poor \\
\hline
\end{tabular}

ions chemistry of lake water, could also be a cause of high nutrient content (Das \& Kaur 2001). The mesotrophic state of its site confirmed that the unusual part of the lake had minimal pollution.

For DI, plant species of 15 different plants were identified. Their abundance ratios were further used to calculate Shannon-Wiener index and Simpson index giving average DI of 2.4 as given in Table 5. Based on the two indices, uniform distribution of the biodiversity was observed with the SWI of 4.784 which is considered higher biodiversity (Jorgenus et al. 2016), whereas SI: 0.002, ranges from 0 to 1 where a lower value implies a higher status of biodiversity.

The overall EHI (Table 6) shows the lake is of medium quality at all the locations except location no.5, which is the rear end of the lake in the range of $1.81-2.47$.

Apart from the findings of this study, the greatest ecological stress on Renuka Lake is cultural siltation/nutrient loading in the form of idol immersion during specific festivals, owing to its holistic relevance, i.e. religious practices/ land tenurial activities. As a high-altitude lake, uncontrolled tourist pressure, followed by increased recreational activities in and around the lake, has been identified as the greatest disturbance/reduction in plant and fauna biodiversity. All these have led to the eutrophic state of the lake and may likely affect the fisheries seriously if periodic timely restoration is not initiated.

\section{Restoration Recommendation}

\section{Pre restoration: source control}

Following are the options that could control the quality of the lake biodiversity index at the source level.

1. To prevent pollution from human wastes, community toilet facilities must be provided around the periphery of the lake.

2. Solid waste management measures could be introduced.

3. Demarcation of lake boundaries could be done with fencing around the lake periphery.

4. Ecotourism should be developed to have better control and management of the lake.

5. Restrictions and guidelines could be developed on the idol/devotee's immersions.

\section{Post Restoration:}

\section{1) Desilting/ Dredging}

Well-organized local and periodic desilting/dredging be undertaken to improve like Truxor amphibious vehicle, dredge pump, floating dredgers, excavators, etc., may be employed to remove silt using a dredge pump. 


\section{2) Bank protection and Plantation}

Non-hazardous dredged sediments may be reused to build up the bank areas that can be planted with a diverse range of native plants, grasses, and wildflowers including Pontederia cordata, sweet flag, flag iris, water mint, gypsywort, Lobelia cardinalis and Native sedges which have lots of benefiting properties thus improving the quality of water. The new riprap plantation is expected to diffuse the energy of spring water entering Renuka Lake, oxygenate it, and help invertebrates and fish. In addition, a new reedbed will be naturally produced to supply food for a variety of birds, including reed warblers, reed bunting, bats, damselflies, dragonflies, and butterflies.

\section{CONCLUSION}

The ecological health of Renuka lake has been assessed based on NSFWQI, CTSI, and Biodiversity index (SWI \& SDI). The results from the analysis and final EHI of Renuka lake reveal that the ecological health of the lake lies in the medium category (Table 6) indicating that lake health in terms of water quality is degrading and it could result in a hyper-eutrophic state if suitable restoration is not timely undertaken by the concern authorities. Also, because Renukaji is a significant temple, worshippers and locals may be able to drink and bathe in the water if the lake changes from eutrophic to oligotrophic. The water, however, is not suitable for drinking due to the presence of E. coli. The Diversity Index showed uniform biodiversity meaning better ecosystem but overall ecological health of Renuka lake in medium quality range. The proper mitigation and timely assessment of the lake are essential for the restoration and revival of the lake. Some other measures are also suggested in addition to the above.

1. Treatment of catchment area through afforestation and use of organic farming.

2. Control of excessive and illegal encroachments of lake catchment.

3. Treatment of human and other wastes through proper treatment and discharge of treated wastewater to the lake through treatment and monitoring WQ of lake

Table 3: Water Quality data and its conversion to NSFWQI.

\begin{tabular}{|c|c|c|c|c|c|c|c|c|c|c|c|c|c|c|}
\hline $\begin{array}{l}\text { Lo- } \\
\text { ca- } \\
\text { tion } \\
\text { No. }\end{array}$ & $\begin{array}{l}\text { Coordinates } \\
\text { Latitude }\end{array}$ & Longitude & $\begin{array}{l}\text { Name of } \\
\text { location }\end{array}$ & $\begin{array}{l}\text { Aver } \\
\text { EC } \\
{[\mu \mathrm{s}]}\end{array}$ & $\begin{array}{l}\text { Salue WQ } \\
\text { Salinity } \\
\text { [PSU] }\end{array}$ & arameter & $\begin{array}{l}\text { BOD } \\
{[\mathrm{mg} .} \\
\left.\mathrm{L}^{-1}\right]\end{array}$ & COD & $\begin{array}{l}\text { DO } \\
{\left[\mathrm{mg} . \mathrm{L}^{-1}\right]}\end{array}$ & $\begin{array}{l}\text { TDS } \\
{[\mathrm{mg} .} \\
\left.\mathrm{L}^{-1}\right]\end{array}$ & $\mathrm{pH}$ & $\begin{array}{l}\text { Temp } \\
{ }^{\circ} \mathrm{C}\end{array}$ & $\begin{array}{l}\text { NSF- } \\
\text { WQI } \\
\text { VAL- } \\
\text { UE }\end{array}$ & $\begin{array}{l}\text { Water } \\
\text { quality } \\
\text { status }\end{array}$ \\
\hline 1 & $30^{\circ} 36^{\prime} 29^{\prime \prime}$ & $77^{\circ} 26{ }^{\prime} 59^{\prime \prime}$ & $\begin{array}{l}\text { Outlet to } \\
\text { Parshuram } \\
\text { tal }\end{array}$ & $\begin{array}{l}394 \\
\pm 40\end{array}$ & $0.2 \pm 0.13$ & $12 \pm 5$ & $\begin{array}{l}10 \\
\pm 10\end{array}$ & $45 \pm 20$ & $\begin{array}{l}5 \\
\pm 2.3\end{array}$ & $189 \pm 33$ & $\begin{array}{l}7.5 \\
\pm 0.61\end{array}$ & $21.7 \pm 0.76$ & 53 & $\begin{array}{l}\text { Medi- } \\
\text { um }\end{array}$ \\
\hline 2 & $30^{\circ} 36^{\prime} 37^{\prime \prime}$ & $77^{\circ} 27^{\prime} 07^{\prime \prime}$ & $\begin{array}{l}\text { Bathing } \\
\text { Ghat }\end{array}$ & $\begin{array}{l}570 \\
\pm 40\end{array}$ & $0.5 \pm 0.13$ & $23 \pm 5$ & $\begin{array}{l}40 \\
\pm 10\end{array}$ & $\begin{array}{l}125 \\
\pm 20\end{array}$ & $2.58 \pm 2.3$ & $\begin{array}{l}277 \\
\pm 33\end{array}$ & $\begin{array}{l}7.4 \\
\pm 0.61\end{array}$ & $20.3 \pm 0.76$ & 40 & Poor \\
\hline 3 & $30^{\circ} 36^{\prime} 35^{\prime \prime}$ & $77^{\circ} 27^{\prime} 00^{\prime \prime}$ & $\begin{array}{l}\text { Recreation- } \\
\text { al area }\end{array}$ & $\begin{array}{l}559 \\
\pm 40\end{array}$ & $0.2 \pm 0.13$ & $17 \pm 5$ & $\begin{array}{l}35 \\
\pm 10\end{array}$ & $90 \pm 20$ & $3.25 \pm 2.3$ & $266 \pm 33$ & $\begin{array}{l}7.5 \\
\pm 0.61\end{array}$ & $22.2 \pm 0.76$ & 45 & Poor \\
\hline 4 & $30^{\circ} 36 \prime 37^{\prime \prime}$ & $77^{\circ} 27^{\prime} 07^{\prime \prime}$ & Dudhdara & $\begin{array}{l}455 \\
\pm 40\end{array}$ & $0.45 \pm 0.13$ & $10 \pm 5$ & $\begin{array}{l}10 \\
\pm 10\end{array}$ & $48 \pm 20$ & $6.5 \pm 2.3$ & $220 \pm 33$ & $\begin{array}{l}7.9 \\
\pm 0.61\end{array}$ & $21.9 \pm 0.76$ & 54 & $\begin{array}{l}\text { Medi- } \\
\text { um }\end{array}$ \\
\hline 5 & $30^{\circ} 36^{\prime} 34^{\prime \prime}$ & $77^{\circ} 27^{\prime} 37^{\prime \prime}$ & $\begin{array}{l}\text { Rare end } \\
\text { area of the } \\
\text { lake }\end{array}$ & $\begin{array}{l}531 \\
\pm 40\end{array}$ & $0.30 \pm 0.13$ & $3 \pm 5$ & $\begin{array}{l}25 \\
\pm 10\end{array}$ & $30 \pm 20$ & $5.5 \pm 2.3$ & $190 \pm 33$ & $\begin{array}{l}7.8 \\
\pm 0.61\end{array}$ & $20 \pm 0.76$ & 59 & $\begin{array}{l}\text { Medi- } \\
\text { um }\end{array}$ \\
\hline
\end{tabular}

Table 4: Analysis of water sample of Renuka lake and its TSI (average of pre- and post-monsoon).

\begin{tabular}{|c|c|c|c|c|c|c|c|c|c|}
\hline \multirow[t]{2}{*}{ S.No. } & \multirow[t]{2}{*}{ Sampling points } & \multicolumn{2}{|c|}{$\begin{array}{l}\text { Secchi Disc Trans- } \\
\text { parency }(\mathrm{m})\end{array}$} & \multicolumn{2}{|c|}{$\begin{array}{l}\text { Total Phosphorous } \\
\left(\mathrm{mg} . \mathrm{L}^{-1}\right)\end{array}$} & \multicolumn{2}{|c|}{$\begin{array}{l}\text { Chlorophyll a } \\
\left(\mu \mathrm{g} . \mathrm{L}^{-1}\right)\end{array}$} & \multirow[t]{2}{*}{ Averga } & \\
\hline & & SD & TSI & $\mathrm{TP}$ & TSI & Chl 'a' & TSI & & \\
\hline 1 & $\begin{array}{l}\text { Out let to Parshuram } \\
\text { tal }\end{array}$ & 1.52 & 53.97 & 35 & 55.42 & 11.5 & 54.56 & 54.7 & Eutrophic \\
\hline 2 & Bathing Ghat & 1.10 & 58.63 & 50 & 60.56 & 15.49 & 57.48 & 58.9 & Eutrophic \\
\hline 3 & Recreational area & 1.15 & 57.98 & 45 & 59.04 & 14.8 & 57 & 58.0 & Eutrophic \\
\hline 4 & Dudhdara & 1.86 & 51.06 & 30 & 53.19 & 7.9 & 50.98 & 51.7 & Eutrophic \\
\hline 5 & Rare end area of lake & 2.05 & 49.60 & 25 & 50.56 & 6.8 & 49.4 & 49.9 & Mesotrophic \\
\hline
\end{tabular}

Carlson's TSI average $=55$ (Eutrophic) 
Table 5: Diversity Index of riparian vegetation around Renuka lake.

\begin{tabular}{|c|c|c|c|c|}
\hline $\begin{array}{l}\text { Species } \\
\text { type }\end{array}$ & $\begin{array}{l}\text { The scientific name of species/ } \\
\text { plant }\end{array}$ & Abundance ratio & $\begin{array}{l}\text { Shannon-Wiener Index } \\
\mathrm{Hi}=\sum \mathrm{p}_{\mathrm{i}} \log \mathrm{p}_{\mathrm{i}}\end{array}$ & $\begin{array}{l}\text { Simpson Index } \\
\mathrm{D}=\Sigma[\text { ni }(\text { ni- } 1) / N(N-1)]\end{array}$ \\
\hline 1 & Saxifragaceae & 0.128 & $2.962 \pm 0.816$ & $0.014 \pm 0.003$ \\
\hline 2 & Terminalia chebula & 0.024 & $5.361 \pm 0.816$ & $0.001 \pm 0.003$ \\
\hline 3 & $\begin{array}{l}\text { Solanum } \\
\text { verbascifolium }\end{array}$ & 0.038 & $4.733 \pm 0.816$ & $0.001 \pm 0.003$ \\
\hline 4 & Vitex nagundo & 0.033 & $4.913 \pm 0.816$ & $0.001 \pm 0.003$ \\
\hline 5 & Woodfordia floribunda & 0.024 & $5.361 \pm 0.816$ & $0.001 \pm 0.003$ \\
\hline 6 & Ziziphus jujube & 0.031 & $5.013 \pm 0.816$ & $0.001 \pm 0.003$ \\
\hline 7 & Salix alba & 0.055 & $4.176 \pm 0.816$ & $0.003 \pm 0.003$ \\
\hline 8 & Albizia lebbeck & 0.022 & $5.498 \pm 0.816$ & $0.000 \pm 0.003$ \\
\hline 9 & Bauhinia variegata & 0.060 & $4.065 \pm 0.816$ & $0.003 \pm 0.003$ \\
\hline 10 & Ficus palmate & 0.053 & $4.235 \pm 0.816$ & $0.002 \pm 0.003$ \\
\hline 11 & Adhatoda vasica & 0.007 & $7.235 \pm 0.816$ & $0.000 \pm 0.003$ \\
\hline 12 & Ageve americana & 0.033 & $4.913 \pm 0.816$ & $0.001 \pm 0.003$ \\
\hline 13 & Anemone obtusiloba & 0.024 & $5.361 \pm 0.816$ & $0.001 \pm 0.003$ \\
\hline 14 & Berberis aristata & 0.027 & $5.235 \pm 0.816$ & $0.001 \pm 0.003$ \\
\hline 15 & Euphorbia royleana & 0.046 & $4.428 \pm 0.816$ & $0.002 \pm 0.003$ \\
\hline 16 & Dodonaeaviscosa & 0.027 & $5.235 \pm 0.816$ & $0.001 \pm 0.003$ \\
\hline 17 & Glycosmis pentaphylla & 0.024 & $5.361 \pm 0.816$ & $0.001 \pm 0.003$ \\
\hline 18 & Indigofera hirsuta & 0.051 & $4.297 \pm 0.816$ & $0.002 \pm 0.003$ \\
\hline 19 & Murraya koenigii & 0.080 & $3.650 \pm 0.816$ & $0.005 \pm 0.003$ \\
\hline 20 & Punica granatum & 0.100 & $3.328 \pm 0.816$ & $0.009 \pm 0.003$ \\
\hline 21 & Berberis chitria & 0.027 & $4.768 \pm 0.816$ & $0.001 \pm 0.003$ \\
\hline 22 & Carissa opaca & 0.022 & $4.858 \pm 0.816$ & $0.000 \pm 0.003$ \\
\hline 23 & Jasminum humile & 0.024 & $4.833 \pm 0.816$ & $0.001 \pm 0.003$ \\
\hline 24 & Lantana camara & 0.069 & $4.838 \pm 0.816$ & $0.004 \pm 0.003$ \\
\hline \multirow[t]{2}{*}{25} & Dhatura suaveolens & 0.049 & $4.835 \pm 0.816$ & $0.002 \pm 0.003$ \\
\hline & Average Index & & 4.780 & 0.002 \\
\hline
\end{tabular}

Table 6: Ecological health Index of Renuka lake.

\begin{tabular}{|lllllllll|}
\hline Sl.no & Name & \multicolumn{2}{ll}{ NSFWQI } & C-STI & & SDI & Overall EHI \\
\hline 1 & Out let to Parshuram tal & 53 & Medium & 54.7 & Eutrophic & 2.4 & 2.14 & medium \\
2 & Bathing Ghat & 40 & Poor & 58.9 & Eutrophic & 2.4 & 2.47 & Medium \\
3 & Recreational area & 45 & Poor & 58.0 & Eutrophic & 2.4 & 2.47 & medium \\
4 & Dudhdara & 54 & Medium & 51.7 & Eutrophic & 2.4 & 2.14 & medium \\
5 & Rare end area of lake & 59 & Medium & 49.9 & Mesotrophic & 2.4 & 1.81 & good \\
\hline
\end{tabular}


4. Public awareness about the benefits of good health of lake through posters, videos, and other mediums

\section{REFERENCES}

APHA 2002. Standard Methods for the Examination of Water and Wastewater. American Public Health Association; American Water Works Association; Water Environment Federation, pp. 1-541.

Cantonati, M., Poikane, S., Pringle, C. M., Stevens, L. E., Turak, E., Heino, J. and Znachor, P. 2020. Natural and artificial freshwater environments : consequences for biodiversity conservation. Water, 12(1): 260.

Carlson, R.E. 1977. A trophic state index for lakes. Limnol. Oceanogr., 22(2): 361-369.

Childs, C. 2004. Interpolating Surfaces in ArcGIS Spatial Analyts. ArcUser, pp. 32-35.

Choden, Y., Badewa, G.K., Cheki, T. and Yangzom, K. 2020. Groundwater quality index of Saharanpur city, India and its spatial representation using geographical information systems. Int. J. Emerg. Technol., 11(4): 157-162.

Das, B.K. and Kaur, P. 2001. Major ion chemistry of Renuka Lake and weathering processes, Sirmaur District, Himachal Pradesh, India. Environ. Geol., 40(7): 908-917.

Diwate, P., Meena, N.K., Bhushan, R., Pandita, S., Chandana, K.R. and Kumar, P. 2020. Sedimentation rate (210Pb and137cs), grain size, organic matter, and bathymetric studies in Renuka lake, Himachal Pradesh, India. Himalayan Geol., 41(1): 51-62.

Hillsborough, M. 2008. Trophic State Index (TSI), in Hillsborough Community Atlas, City of Tampa, Florida: Hillsborough County; URL: www. hillsborough.community atlas.usf.edu.

Himachal Pradesh Council For Science,Technology \& Environment 2017. Major Wetlands of Himachal Pradesh. Himachal Pradesh State Wetland Authority, pp. 1-22.

Jorgenus, S.E., Costanza, R. and Fu liu, X. 2016. Handbook of Ecologi- cal Indicators for Assessment of Ecosystem Health. Taylor Francis, London, UK.

Joshi. 2013. SERI News. Retrieved from http://seriecotech.com/ blog/?p=377. Accessesed 7, 2013

Kumar, A., Mishra, S. and Sharma, M.P. 2015. Assessment of ecological health of Baiyangdian lake in China using ecological health index. J. Appl. Natural Sci., 7(2): 955-959.

Mendes, R. S., Evangelista, L. R., Thomaz, S. M., Agostinho, A. A. and Gomes, L. C. 2008. A unified index to measure ecological diversity and species rarity. Ecography, 31(4): 450-456.

Mishra, S., Sharma, M.P. and Kumar, A. 2016. Ecological health assessment of Surha Lake, India. J. Mater. Environ. Sci., 7(5): 1708-1715.

Ozturk, D. and Kilic, F. 2016. Geostatistical approach for spatial interpolation of meteorological data. An. Acad. Bras. Cienc., 88(4): 2121-2136.

Pavluk, T. and Abraham, B.D.V. 2018. Trophic index and efficiency. In Fath, B. (ed.), Reference Module in Earth Systems and Environmental Sciences: Encylocpadeia of Ecology, 2nd edition, Elseiver, The Netherlands, pp. 495-502

Pillai, S. 2003. Information Sheet on Ramsar Wetlands - Solent. Ramsar, 1-8.

Sharma, M. 2014. Water quality assessment of the Central Himalayan Lake, Nainital. Advances in Environmental Chemistry, Hindawi Publishing Corporation, pp. 1-5.

Sharma, M. P., Kumar, A. and Rajvanshi, S. 2010. Assessment of trophic state of lakes: a case of Mansi Ganga Lake in India. Hydro Nepal: Journal of Water, Energy and Environment, 6(6): 65-72.

Singh, O.K and Sharma M. K. 2012. Water quality and eutrophication of Renuka lake, Sirmaur district (H.P.). J. Indian Water Resour.Soc., 32: 3-4.

Sunil, C., Somashekar, R.K. and Nagaraja, B.C. 2016. Diversity and composition of riparian vegetation across forest and agroecosystem landscapes of river Cauvery, southern India. Trop. Ecol., 57(2): 343-354.

Tyagi, S., Sharma, B., Singh, P. and Dobhal, R. 2020. Water quality assessment in terms of water quality index. Am. J. Water Resour., 1(3): 34-38.

Yadav, N.S., Sharma, M.P. and Kumar, A. 2015. Assessment of ecological health of Chambal River using plant species diversity. J. Mater. Environ. Sci., 6(9): 2624-2630. 